\title{
Improving Washington Navel Orange Fruits by Some Natural Pre-Harvest Foliar Applications A- Mineral Content, Yield and Fruit Quality
}

\author{
Ezz, Thanaa M. * , Aly, M. A.* , Ekbal, Z. A. Ahmed**, Rehab, M. Awad* \\ and Abd El-Gawad, M. G. ** \\ *Plant Production Department - Faculty of Agriculture (Saba Basha) - Alexandria \\ University \\ **Sabahia Horticulture Research Station, Alexandria - Agriculture Research Centre
}

\begin{abstract}
This investigation was carried out during the two successive seasons of (2013 and 2014) on 20-years-old Washington Navel orange (Citrus sinensis L. Osbeck) trees budded on sour orange (Citrus aurantium L.) rootstock grown in clay soil in a private orchard at Kafr El-Dawar region, EL-Behira Governorate, Egypt, to improve mineral contents, yield and fruit quality by pre-harvest foliar applications with Putrescine at $(2,4$ and $6 \mathrm{mM})$, Spermine at (2, 4 and $6 \mathrm{mM}$ ), Jasmine Oil at $(0.04,0.06$ and $0.08 \%)$, Thyme Oil at (0.04, 0.06 and $0.08 \%)$, Garlic Extract at (1, 1.5 and $2 \%)$, Clove Extract at (1, 1.5 and $2 \%)$, Algaefol Extract at (1, 1.5 and $2 \%$ ), Jisamar Extract at (1, 1.5 and $2 \%$ ) and control (untreated trees).

Four foliar spraying were carried on trees from each treatment as follows, the first application was just at full bloom for Washington Navel orange trees. The second application was after 30 days from the first one, the third application was after 30 days from the second and the fourth application was before 45 days from the harvest date. The obtained results revealed that all foliar applications improved leaf mineral contents and increased yield as (number of fruits and weight $\mathrm{kg}$ per tree), average fruit weight compared with control, while it clearly decreased pre-harvest fruit drop during two seasons. Moreover, it improved TSS, acidity, vitamin C, TSS/Acid ratio, total sugars, reducing sugars and non-reducing sugars contents compared with the control. In addition, the two higher concentrations of all treatments were more effective than the low concentration on improving yield, mineral content and fruit quality of Washington Navel orange fruits.
\end{abstract}

Keywords: Washington Navel orange, Polyamines, Jasmine Oil, Thyme Oil, Garlic Extract, Clove Extract, Seaweed Extract.

\section{INTRODUCTION}

Citrus fruits occupy the first rank among economic fruit crops in Egypt as well as all over the world. Orange is the most important citrus crop in Egypt. Washington Navel orange (Citrus sinensis L. Osbeck) is one of the most popular citrus fruits in Egypt, for its delicious taste and nutrition, besides being rich in vitamin $\mathrm{C}$ and minerals. It has a significant importance not only in the local market but also for export. Under Egyptian conditions, it is a common practice to store mature Navel orange fruits on the trees for long time to delay harvest time but this cause some effect on flowering of the following season.

Several natural compounds have been used to retard ripening and extend fruit shelf life. For instance polyamines are group of natural compounds that are believed to have anti-senescence function by inhibition of the formation of enzymes essential to the synthesis of ethylene (Ke and Romani 1988). Association between the sprayed substances (especially putrescine) and ethylene has been recently reviewed and investigated (Pandey et al., 2000, Giovannoni, 2001 and Valero et al., 2002). In this sense, there is evidence of an interrelationship between ethylene and polyamines during fruit ripening and senescence (Pandey et al., 2000). They play an inhibitory role on ethylene 
production through inhibition of ACC synthetase and ACC oxidase (Apelbaum et al., 1981, Lee et al., 1997), thus delaying ethylene emission. Polyamines have been reported to reduce softening, delay senescence and reduce decay in several fruits (Saftner and Baldi 1990, Kramer et al., 1991).

Jasmine and thyme oils some of these essential oils are effective in this respect, it may slow some vital processes such as, respiration while enhance juvenility, lowering consumption of sugars by hindering ethylene action and retarding the quick senescence of plant organs and in turn utilization of sugars (Paulin, 1986).

Use of natural components such as natural extract or herbal oils is one of the healthiest and safest methods to control postharvest diseases. Herbal essential oils include extensive secondary metabolites, which in most cases have antimicrobial, fungicidal, allelopathy, antioxidant and bio-regulating properties (Asghari et al., 2009). In the view of chemical, essential oils are complex components with different kinds of chemical substances including: hydrocarbons, alcohols, cetons, and aldehydes (zargari, 1992). Thymus essential oil is known to contain more than $40 \%$ of phenolic compositions (thymol and carvacrol), that have strong antiseptics effect. In addition to thymole, caffeic acid and thanin existing in essential oil can effectively prevent growth of bacteria, fungus and viruses. The highest value of thymole exists in Thymus vulgaris. According to GC analysis, Thymus captatus contains carvacrol that researchers pointed to its anti microbial property and inhibition activity of the existence of these two compounds (Karimi and Rahemi, 2009).

Plant extracts have effectively inhibited sprouting relative to control (ElSharkawy, 1998). In recent reports (Avato et al., 2000) suggested that volatile compounds of garlic such as diallylmonosulfide, diallyldisulfide, and diallyltrisulfide were also found to have antimicrobial properties. The inhibitory activity of clove is due to the presence of several constituents, mainly eugenol, eugenyl acetate, beta-caryophyllene, 2-heptanone (Chaieb et al., 2007), acetyleugenol, alpha-humulene, methyl salicylate, iso-eugenol, methyl-eugenol (Yang et al., 2003), phenyl propanoides, dehydrodieugenol, trans-confireryl aldehyde, biflorin, kaempferol, rhamnocitrin, myricetin, gallic acid, ellagic acid and oleanolic acid (Cai and Wu, 1996).

Seaweed products exhibit growth-stimulating activities, and the use of seaweed formulations as biostimulants in crop production is well established. Biostimulants are defined as materials, other than fertilizers, that promote plant growth when applied in small quantities" and are also referred to as "metabolic enhancers" (Zhang and Schmidt, 1997). Seaweed components such as macroand microelement nutrients, amino acids, vitamins, cytokinins, auxins and abscisic acid (ABA)-like growth substances affect cellular metabolism in treated plants leading to enhanced growth and crop yield (Reitz and Trumble, 1996).

Therefore, this investigation was carried out during the two successive seasons of 2013 and 2014 in order to study the effectiveness of pre-harvest spraying of Putrescine, Spermine, Jasmine oil, Thyme oil, Garlic Extract, Clove 
extract, Algaefol extract and Jisamar extract treatments on mineral contents, yield and fruit quality of Washington Navel orange cultivar.

\section{MATERIALS AND METHODS}

This investigation was carried out during the two successive seasons of (2013 and 2014) on 20-years-old Washington Navel orange (Citrus sinensis L. Osbeck) trees budded on sour orange (Citrus aurantium L.) rootstock, to improve mineral content, yield and fruit quality by some natural pre-harvest foliar applications. Trees were growing in clay soil in a private orchard at Kafr El-Dawar region, EL-Behira governorate, Egypt. Trees received normal horticultural practices including: surface irrigation, fertilization, pruning, as well as pest and disease control. The trees were planted at $(4.0 \times 4.5)$ meters apart. At the beginning of this study, samples of soil were taken from (0-30, 30-60 and $60-90 \mathrm{~cm}$ depth) at 4 different sites of major parts of zone before adding any fertilizers to determine some physical and chemical characters of the soil. The obtained results are presented in Table (1). Soil orchard was clay with a water table about $125 \mathrm{~cm}$ far from the soil surface.

The orchard was fertilized at February of each experimental season, with organic manure at rate of (15) cubic meters per feddan. Besides, at March of each experimental season, the trees were fertilized with $200 \mathrm{~kg}$ ammonium nitrate $(33.5 \% \mathrm{~N})$ and $100 \mathrm{~kg}$ potassium sulphate $\left(48 \% \mathrm{~K}_{2} \mathrm{O}\right)$ per feddan. In addition, for each experimental season, at May the trees were fertilized with 100 $\mathrm{kg}$ ammonium nitrate $(33.5 \% \mathrm{~N})$, at August the trees were fertilized with $200 \mathrm{Kg}$ ammonium nitrate $(33.5 \% \mathrm{~N})$ and $100 \mathrm{~kg}$ potassium sulphate $\left(48 \% \mathrm{~K}_{2} \mathrm{O}\right)$ per feddan.

Table (1): Soil Analysis of the experimental orchard

\begin{tabular}{|c|c|c|c|c|c|c|c|c|c|c|}
\hline \multirow{2}{*}{$\begin{array}{l}\text { Soil Depth } \\
\quad \text { (cm) }\end{array}$} & \multirow{2}{*}{ Texture } & \multirow{2}{*}{ pH } & \multirow{2}{*}{$\begin{array}{c}\text { E.C } \\
(\mathrm{dS} / \mathrm{m})\end{array}$} & \multicolumn{4}{|c|}{$\begin{array}{c}\text { Soil Content of Cations } \\
(\mathrm{meq} / \mathrm{L})\end{array}$} & \multicolumn{3}{|c|}{$\begin{array}{c}\text { Soil Content of Anions } \\
(\mathrm{meq} / \mathrm{L})\end{array}$} \\
\hline & & & & $\mathbf{K}^{+}$ & $\mathrm{Na}^{+}$ & $\mathrm{Ca}^{+2}$ & $\mathrm{Mg}^{+2}$ & $\mathrm{HCO}_{3}^{-}$ & $\mathrm{Cl}^{-}$ & $\mathrm{SO}_{4}{ }^{-2}$ \\
\hline$(0-30)$ & clay & 7.74 & 1.03 & 0.45 & 5.90 & 2.50 & 1.50 & 2.32 & 2.25 & 2.78 \\
\hline$(30-60)$ & clay & 7.55 & 0.95 & 0.33 & 3.70 & 4.50 & 1.00 & 2.90 & 5.00 & 5.50 \\
\hline$(60-90)$ & clay & 7.45 & 1.00 & 0.29 & 3.90 & 4.00 & 2.00 & 2.90 & 5.50 & 1.79 \\
\hline
\end{tabular}

Seventy five uniform trees distributed in the orchard were selected for this investigation. In April of the two growing seasons, twenty shoots from all over the outer circumference of each tree were tagged in order to secure leaf samples of the same age. Leaf samples were collected at two weeks intervals from each of the selected trees during August, 15 to August, 31 in both seasons. This experiment was laid-out in completely randomized design (CRD) with three replications. Each treatment was represented in three trees.

\section{The following treatments were carried out:}

1. Untreated trees (control).

2. Putrescine $(2,4$ and $6 \mathrm{mM} / \mathrm{L})$.

3. Spermine $(2,4$ and $6 \mathrm{mM} / \mathrm{L})$.

4. Jasmine Oil $(0.04,0.06$ and $0.08 \%)$. 
5. Thyme Oil $(0.04,0.06$ and $0.08 \%)$.

6. Garlic Extract (1, 1.5 and $2 \%)$.

7. Clove Extract (1,1.5 and $2 \%)$.

8.Algaefol Extract (1, 1.5 and $2 \%)$.

9. Jisamar Extract (1, 1.5 and $2 \%)$.

- Polyamines (Putrescine and Spermine) are obtained from TRADING DYNAMIC COMPANY - 5, El Wehda El Arabia St., Pyramides Way, Giza-Egypt.

- Jasmine oil and Thyme oil (commercial solution) are obtained from arrow companya public sector Company related to El Hawamdia Company for sugar refinement.

i. A concentration of $0.04 \%$ was prepared directly by dissolving $1.5 \mathrm{~cm}^{3}$ jasmine oil in 5 liters of water.

ii. Other concentrations of $(0.06 \%$ and $0.08 \%)$ were prepared on the same basis.

\section{Preparation of plant extracts}

Plant materials were dried in the shade (clove peels and garlic bulbs) were washed with distilled water and dried in shade. They were finely grinded to powder. Fifty grams of each plant material in powder form was homogenized by laboratory blender in $200 \mathrm{ml}$ of methanol (96\%) and distilled water (20:80 v/v) for $10 \mathrm{~min}$, and then left in dark glass bottles for $72 \mathrm{~h}$ for complete extraction. The extracts were filtered through thin cheesecloth sheets. The final extracts were collected separately in other dark glass bottles and exposed to $60^{\circ} \mathrm{C}$ in water bath for 30 min for methanol evaporation. The collected extracts were then stored in a refrigerator at $5^{\circ} \mathrm{C}$ until needed. Plant extracts was subjected to GC-MS analysis using a Gas Chromatograph (Table, 2) (Singh et al., 2005).

Table (2): Functional components of clove and garlic extracts by GC- MS analysis

\begin{tabular}{l|c|l|c}
\hline Clove extract parameters & $(\boldsymbol{\%})$ & \multicolumn{1}{|c}{ Garlic extract parameters } & $\mathbf{( \% )}$ \\
\hline Eugenol & 75.30 & Diallyl sulfide & 33.67 \\
Eugenyl acetate & 4.55 & Diallyl disulfide & 10.31 \\
Beta-Caryophyllene & 15.20 & Allyl methyl sulfide & 8.96 \\
Alpha-Humulene & 2.10 & 3-vinyl-1,2-dithiole-5-cyclohexene & 28.19 \\
Cadenine & 1.05 & Vinyl-1,2-thia-4-cyclohexene & 10.26 \\
2-Heptanone & 0.90 & Methyl sulfide & 8.61 \\
(E)-B-Ocimene & 0.30 & & \\
p-Allyl phenol & 0.20 & & \\
Ą-Copaene & 0.10 & & \\
Caryophyllene oxide & 0.10 & & \\
Gallic acid & 0.09 & & \\
Ellagic acid & 0.08 & & \\
Oleanolic acid & 0.03 & & \\
\hline
\end{tabular}

Four foliar spraying were carried out to trees from each treatment as follows: The first application was just at full bloom for Washington Navel orange trees. The second application was after 30 days from the first one, the third application was after 30 days from the second and the fourth application was 
before 45 days from the harvest date. At harvest on maturity stage (late November), under the experimental conditions, the yield per tree was determined.

\section{The following determinations were carried out:}

\section{Leaf mineral content:}

Leaf samples were collected from each replicate. Leaf samples were carefully taken out washed with tap water followed by distilled water several time. The samples were oven dried at $70^{\circ} \mathrm{C}$ until constant weight and ground in stainless steel rotary mill, $(0.3 \mathrm{~g})$ of this dried samples was used for preparing the wet digestion procedure by using sulphoric acid and hydrogen peroxide $\left(\mathrm{H}_{2} \mathrm{O}_{2}\right)$ as described by (Evenhuis and Dewaard, 1980). The digested solution was kept in brown bottle until the determination of minerals.

Nitrogen and Phosphorus were determined colorimetrically according to (Evenhuis, 1976) and (Murphy and Riley, 1962), respectively. Potassium was determined by flame photometer and calcium, magnesium, iron, manganese, zinc and copper by Perkin Elmer Atomic Absorption spectrophotometer model 305 B. The concentration of nitrogen, phosphorus, potassium, calcium and magnesium were expressed as percent, while those of iron, copper, zinc and manganese were expressed as parts per million on dry weight basis.

\section{Fruit drop:}

To study the fruit drop percentages remainder fruits were calculated at June in both seasons through the following equation:

Number of Developed Fruitlets - Number of Remained Fruits Fruit drop \% =

Number of Developed Fruitlets

\section{Yield:} as follows:

Number of fruits per tree were calculated and total yield was determined

Total Yield $(\mathrm{kg} /$ tree $)=$ Number of Fruits $\times$ Average of Fruit Weight

\section{Physical properties:}

4. 1. Average fruit weight $(\mathrm{g})$ :

\section{Chemical properties:}

\subsection{Total soluble solids percentage:}

A hand refractometer was used to determine the total soluble solids percentage in fruit juice.

\subsection{Vitamin C (Ascorbic Acid):}

Vitamin $\mathrm{C}$ content was determined in fruit juice using 2,6- dichlorophenolindo-phenol blue dye as $\mathrm{mg}$ ascorbic acid per $100 \mathrm{ml}$ Juice. (A.O.A.C., 1980). 


\subsection{Acidity percentage:}

Fruit juice acidity was determined according to (A.O.A.C., 1980) by titration with $0.1 \mathrm{~N}$ sodium hydroxide using phenolphthalein as an indicator and expressed as citric acid percentage.

\subsection{TSS/Acid ratio:}

\subsection{Sugars determination:}

For sugars determination, the flesh of each fruit sample was cut into small pieces by a clean knife and mixed well. Five grams of the cut flesh were taken and extracted by distilled water according to (A.O.A.C., 1980). The total sugars were determined calorimetrically using phenol and sulphuric acid according to (Malik and Singh, 1980). The reducing sugars were determined by the Nelson arsenate-molybdate colorimetric method (Dubois et al., 1956). The nonreducing sugars were calculated by the difference between total sugars and reducing sugars.

\section{Statistical analysis:}

Data of the present study were subjected to the analysis of variance test (ANOVA) as completely randomized design (CRD). The least significant differences (LSD) at the $5 \%$ level of probability were calculated using a computer program Costat according to Snedecor and Cochran (1980).

\section{RESULTS AND DISCUSSION}

\section{Leaf mineral content:}

Data concerning the effect of some natural pre-harvest foliar applications on leaf mineral contents in Washington Navel orange trees in 2013 and 2014 seasons are shown in Tables (3 and 4). Statistical analysis of the present data indicated that, in both seasons, all foliar treatments caused a significant increase in leaf macro elements $\mathrm{N}, \mathrm{P}, \mathrm{K}, \mathrm{Ca}$ and $\mathrm{Mg}$ compared with the control. Moreover, Garlic Extract at (1.5 and 2)\%, Clove Extract at (1.5 and 2)\%, Algaefol Extract at (1.5 and 2)\% and Jisamar Extract at (1.5 and 2)\% were more effective on increasing leaf macro elements than that other treatments, Table (3). These results might be attributed to the higher own content of these applications from pigments, antioxidants and nutrients which reflected on encouraging cell division and the biosynthesis of organic foods (Srimal, 1997; Norric et al., 2002 and Bruneton, 2011). The higher own content of seaweed extract from essential nutrients, organic compounds, enzymes, vitamins and natural hormones (Verkleij, 1992) could explain the present results. The beneficial effect of seaweed extract (SWE) on uptake of nutrients, resistance of plants to most stresses and the incidence of fungal and insect attack (Cassan et al., 1992) give another explanation. These results are in agreement with those obtained by Hegab et al. (2005) working on Balady orange and they found that leaf $\mathrm{N}, \mathrm{P}$ and $\mathrm{K}$ content increased with increasing rates of algae extract. As well as Abd El-Motty et al. (2010), Mohamed et al. (2012), Mohamed and ElSehrawy (2013) spraying different varieties of mango trees with seaweed extract (SWE). They reported that leaf content of N, P and $\mathrm{K}$ was significantly higher in the trees treated with Algae extract rather than non- application. 
As for the micro elements iron, copper, zinc and manganese content, results in Table (4) for 2013 and 2014 seasons showed that, in both seasons, all foliar treatments caused a significant increase in leaf micro elements compared with the control. In addition, Putrescine at $(6 \mathrm{mM})$, Spermine at $(6$ $\mathrm{mM})$, Garlic Extract at (2\%), Clove Extract at (2\%), Algaefol Extract at (2\%) and Jisamar Extract at $(2 \%)$ were more effective on increasing leaf micro elements than that other treatments.

Table (3):Effect of some natural pre-harvest foliar applications on leaf macro elements percent (dry weight basis) of Washington Navel orange trees in 2013 and 2014 seasons

\begin{tabular}{|c|c|c|c|c|c|c|c|c|c|c|}
\hline \multirow{2}{*}{ Treatments } & \multicolumn{2}{|c|}{$\mathbf{N}(\%)$} & \multicolumn{2}{|c|}{$\mathbf{P}(\%)$} & \multicolumn{2}{|c|}{$\mathbf{K}(\%)$} & \multicolumn{2}{|c|}{$\mathrm{Ca}(\%)$} & \multicolumn{2}{|c|}{$\operatorname{Mg}(\%)$} \\
\hline & 2013 & 2014 & 2013 & 2014 & 2013 & 2014 & 2013 & 2014 & 2013 & 2014 \\
\hline Control (Water Only) & 1.37 & 1.33 & 0.14 & 0.15 & 0.40 & 0.41 & 1.94 & 1.46 & 0.27 & 0.25 \\
\hline Putrescine (2 mM) & 1.75 & 1.82 & 0.16 & 0.18 & 0.46 & 0.48 & 2.17 & 1.95 & 0.31 & 0.30 \\
\hline Putrescine (4 mM) & 1.76 & 1.89 & 0.18 & 0.20 & 0.50 & 0.52 & 2.35 & 2.10 & 0.32 & 0.31 \\
\hline Putrescine $(6 \mathrm{mM})$ & 1.82 & 2.00 & 0.19 & 0.22 & 0.53 & 0.55 & 2.63 & 2.30 & 0.34 & 0.33 \\
\hline Spermine $(2 \mathrm{mM})$ & 1.76 & 1.77 & 0.17 & 0.18 & 0.47 & 0.48 & 2.21 & 2.01 & 0.31 & 0.29 \\
\hline Spermine (4 mM) & 1.78 & 1.85 & 0.18 & 0.20 & 0.51 & 0.52 & 2.43 & 2.12 & 0.33 & 0.31 \\
\hline Spermine $(6 \mathrm{mM})$ & 1.83 & 1.99 & 0.19 & 0.22 & 0.54 & 0.56 & 2.68 & 2.30 & 0.35 & 0.33 \\
\hline Jasmine Oil (0.04 \%) & 1.78 & 1.82 & 0.16 & 0.17 & 0.47 & 0.48 & 2.11 & 1.98 & 0.30 & 0.29 \\
\hline Jasmine Oil $(0.06 \%)$ & 1.81 & 1.88 & 0.17 & 0.20 & 0.51 & 0.53 & 2.35 & 2.08 & 0.32 & 0.30 \\
\hline Jasmine Oil $(0.08 \%)$ & 1.84 & 1.95 & 0.18 & 0.21 & 0.54 & 0.56 & 2.53 & 2.14 & 0.33 & 0.32 \\
\hline Thyme Oil (0.04 \%) & 1.79 & 1.81 & 0.16 & 0.18 & 0.48 & 0.48 & 2.16 & 2.03 & 0.30 & 0.39 \\
\hline Thyme Oil $(0.06 \%)$ & 1.81 & 1.89 & 0.18 & 0.20 & 0.52 & 0.53 & 2.44 & 2.06 & 0.32 & 0.31 \\
\hline Thyme Oil (0.08 \%) & 1.85 & 1.97 & 0.19 & 0.21 & 0.55 & 0.56 & 2.58 & 2.18 & 0.34 & 0.32 \\
\hline Garlic Extract (1\%) & 1.82 & 1.91 & 0.17 & 0.19 & 0.49 & 0.52 & 2.19 & 2.10 & 0.32 & 0.30 \\
\hline Garlic Extract (1.5\%) & 1.87 & 1.98 & 0.19 & 0.20 & 0.54 & 0.55 & 2.49 & 2.23 & 0.35 & 0.31 \\
\hline Garlic Extract $(2 \%)$ & 1.96 & 2.09 & 0.20 & 0.22 & 0.55 & 0.57 & 2.74 & 2.35 & 0.36 & 0.33 \\
\hline Clove Extract ( $1 \%)$ & 1.85 & 1.92 & 0.17 & 0.19 & 0.50 & 0.52 & 2.23 & 2.09 & 0.32 & 0.30 \\
\hline Clove Extract $(1.5 \%)$ & 1.92 & 1.98 & 0.19 & 0.21 & 0.54 & 0.56 & 2.52 & 2.26 & 0.36 & 0.31 \\
\hline Clove Extract ( $2 \%)$ & 2.02 & 2.08 & 0.20 & 0.22 & 0.56 & 0.58 & 2.75 & 2.35 & 0.36 & 0.33 \\
\hline Algaefol Extract (1\%) & 1.85 & 1.93 & 0.18 & 0.19 & 0.52 & 0.54 & 2.18 & 2.08 & 0.32 & 0.30 \\
\hline Algaefol Extract(1.5\%) & 1.92 & 2.02 & 0.19 & 0.21 & 0.55 & 0.58 & 2.56 & 2.25 & 0.33 & 0.31 \\
\hline Algaefol Extract (2\%) & 2.04 & 2.08 & 0.20 & 0.22 & 0.57 & 0.60 & 2.71 & 2.39 & 0.36 & 0.32 \\
\hline Jisamar Extract (1\%) & 1.87 & 1.94 & 0.18 & 0.19 & 0.52 & 0.54 & 2.19 & 2.10 & 0.32 & 0.29 \\
\hline Jisamar Extract (1.5\%) & 1.93 & 1.99 & 0.19 & 0.20 & 0.56 & 0.58 & 2.58 & 2.30 & 0.34 & 0.31 \\
\hline Jisamar Extract (2\%) & 2.05 & 2.09 & 0.20 & 0.21 & 0.57 & 0.61 & 2.74 & 2.41 & 0.36 & 0.32 \\
\hline LSD at $_{0.05}$ & 0.06 & 0.05 & 0.01 & 0.01 & 0.02 & 0.05 & 0.12 & 0.10 & 0.01 & 0.01 \\
\hline
\end{tabular}

In harmony with these results are those obtained by Mohamed and ElSehrawy (2013) spraying "Hindy Bisinnara" mango trees with seaweed extract (SWE) twice, thrice or four times at $0.0,0.1,0.2$ and $0.4 \%$. They found that, application of seaweed extract (SWE) spraying via leaves at 0.1 to $0.4 \%$ significantly was accompanied with stimulating the leaf content of $\mathrm{Mg}, \mathrm{Zn}, \mathrm{Fe}$ and $\mathrm{Mn}$ rather than non-application. The promotion was significantly associated with increasing seaweed extracts concentrations. 


\section{Fruit drop:}

Data of studying the effect of some natural pre-harvest foliar applications on pre-harvest fruit drop percentage of Washington Navel orange trees are listed in Table (5). Results showed that, in both seasons, all treatments caused a significant decrease in pre-harvest fruit drop percentage compared with the control. Moreover, in the two seasons of this study, the statistical analysis showed that Putrescine at $6 \mathrm{mM}$, Spermine at $6 \mathrm{mM}$, Garlic Extract at $2 \%$ and Clove Extract at $2 \%$ were more effective on decreasing pre-harvest fruit drop than that of other treatments. The positive influence on decreasing fruit drop by the sprayed substances in our study in obvious. It is well established that plant growth regulators are involved in control of abscission (Sexton and Robersts, 1982). Ethylene accelerates mature citrus fruit abscission, and as previously mentioned that putrescine inhibits ethylene production, this might explain its effect on decreasing fruit drop.

Table (4): Effect of some natural pre-harvest foliar applications on leaf micro elements content (part per million) of Washington Navel orange trees in 2013 and 2014 seasons

\begin{tabular}{|c|c|c|c|c|c|c|c|c|}
\hline \multirow{2}{*}{ Treatments } & \multicolumn{2}{|c|}{$\mathrm{Fe}(\mathrm{ppm})$} & \multicolumn{2}{|c|}{$\mathrm{Cu}(\mathbf{p p m})$} & \multicolumn{2}{|c|}{ Zn (ppm) } & \multicolumn{2}{|c|}{ Mn (ppm) } \\
\hline & 2013 & 2014 & 2013 & 2014 & 2013 & 2014 & 2013 & 2014 \\
\hline Control (Water Only) & 144.93 & 143.66 & 29.25 & 28.56 & 38.90 & 39.10 & 19.68 & 18.92 \\
\hline Putrescine $(2 \mathrm{mM})$ & 151.23 & 150.90 & 32.14 & 32.16 & 41.46 & 41.71 & 22.73 & 20.91 \\
\hline Putrescine (4 mM) & 152.70 & 152.00 & 33.41 & 33.55 & 42.26 & 42.56 & 23.80 & 23.08 \\
\hline Putrescine $(6 \mathrm{mM})$ & 153.90 & 153.43 & 36.05 & 36.32 & 43.50 & 43.68 & 24.61 & 24.47 \\
\hline Spermine $(2 \mathrm{mM})$ & 151.26 & 150.86 & 31.54 & 31.75 & 41.43 & 41.78 & 22.91 & 22.04 \\
\hline Spermine (4 mM) & 152.53 & 151.90 & 33.14 & 33.00 & 42.08 & 42.86 & 24.16 & 23.43 \\
\hline Spermine (6 mM) & 153.86 & 153.26 & 36.12 & 36.32 & 43.06 & 43.76 & 24.88 & 24.45 \\
\hline Jasmine Oil (0.04 \%) & 150.40 & 149.90 & 31.06 & 30.64 & 40.21 & 40.91 & 22.73 & 21.35 \\
\hline Jasmine Oil (0.06 \%) & 151.30 & 150.76 & 32.44 & 32.72 & 41.95 & 42.16 & 23.89 & 23.17 \\
\hline Jasmine Oil (0.08 \%) & 152.63 & 151.83 & 35.63 & 35.77 & 42.81 & 43.20 & 24.70 & 24.64 \\
\hline Thyme Oil (0.04 \%) & 150.03 & 150.00 & 30.92 & 30.78 & 40.03 & 40.40 & 22.73 & 22.21 \\
\hline Thyme Oil (0.06 \%) & 151.36 & 150.93 & 32.16 & 32.16 & 41.88 & 42.20 & 23.98 & 23.60 \\
\hline Thyme Oil (0.08 \%) & 152.70 & 152.50 & 35.02 & 35.49 & 42.83 & 43.26 & 24.61 & 24.64 \\
\hline Garlic Extract (1\%) & 152.06 & 151.53 & 32.86 & 33.00 & 41.83 & 42.33 & 23.09 & 23.43 \\
\hline Garlic Extract (1.5\%) & 153.00 & 152.96 & 35.35 & 35.35 & 42.75 & 43.08 & 24.34 & 24.47 \\
\hline Garlic Extract (2\%) & 153.50 & 153.82 & 36.60 & 36.88 & 43.61 & 44.00 & 24.97 & 25.51 \\
\hline Clove Extract (1\%) & 152.13 & 151.56 & 32.86 & 32.58 & 41.73 & 41.81 & 23.35 & 23.69 \\
\hline Clove Extract (1.5\%) & 152.76 & 152.50 & 35.63 & 35.69 & 42.58 & 42.93 & 24.34 & 24.81 \\
\hline Clove Extract (2\%) & 153.40 & 153.25 & 36.74 & 36.88 & 43.68 & 43.95 & 24.88 & 25.86 \\
\hline Algaefol Extract (1 \%) & 152.06 & 151.86 & 35.77 & 33.00 & 41.46 & 41.52 & 23.62 & 23.43 \\
\hline Algaefol Extract (1.5\%) & 153.00 & 152.82 & 35.91 & 35.63 & 42.71 & 42.88 & 24.25 & 24.47 \\
\hline Algaefol Extract (2\%) & 153.70 & 153.26 & 36.74 & 36.74 & 43.71 & 43.98 & 24.79 & 25.51 \\
\hline Jisamar Extract (1\%) & 151.93 & 151.06 & 32.86 & 32.72 & 41.31 & 41.13 & 23.80 & 24.47 \\
\hline Jisamar Extract (1.5\%) & 153.20 & 152.86 & 35.91 & 36.05 & 42.60 & 42.71 & 24.37 & 24.99 \\
\hline Jisamar Extract (2 \%) & 154.00 & 153.85 & 36.88 & 37.02 & 43.73 & 44.03 & 24.70 & 25.51 \\
\hline $\mathrm{LSD}_{\text {at }}{ }_{0.05}$ & 0.87 & 0.63 & 1.04 & 0.77 & 0.51 & 0.52 & 1.62 & 1.16 \\
\hline
\end{tabular}

In addition, Jasmine oil may slow some vital processes, such as respiration while enhance juvenility and retarding the quick senescence of plant organs (Paulin, 1986). These results are in agreement with those obtained by Abd El-Motty et al. (2010) spraying Keitte mango trees with algae extract at $(0.5,1$ and $2 \%)$ at full bloom stage. They reported that seaweed extract 
treatments were very effective in reducing fruit drop comparing with the control. Zaghloul et al. (2011) spraying activated jasmine oil on Navel orange trees and they found that the highest rate of jasmine oil $(0.06 \%)$ clearly decreased preharvest fruit drop. Moreover, Kassem et al. (2012) spraying Washington Navel orange trees with Putrescine and they found that all spray treatments decreased fruit drop.

Table (5): Effect of some natural pre-harvest foliar applications on preharvest fruit drop (\%), fruit weight $(\mathrm{gm})$ and yield as (No. of fruits per tree and kilograms per tree) of Washington Navel orange trees in 2013 and 2014 seasons

\begin{tabular}{|c|c|c|c|c|c|c|c|c|}
\hline \multirow[t]{2}{*}{ Treatments } & \multicolumn{2}{|c|}{$\begin{array}{c}\text { Pre-harvest } \\
\text { Fruit } \\
\text { Drop (\%) }\end{array}$} & \multicolumn{2}{|c|}{$\begin{array}{c}\text { Fruit Weight } \\
(\mathrm{g})\end{array}$} & \multicolumn{2}{|c|}{$\begin{array}{l}\text { No. of Fruits } \\
\text { per Tree }\end{array}$} & \multicolumn{2}{|c|}{$\begin{array}{c}\text { Yield } \\
\text { (kg) per Tree }\end{array}$} \\
\hline & 2013 & 2014 & 2013 & 2014 & 2013 & 2014 & 2013 & 2014 \\
\hline Control (Water Only) & 11.76 & 11.72 & 199.33 & 201.00 & 295 & 296 & 58.79 & 59.47 \\
\hline Putrescine (2 mM) & 8.54 & 8.78 & 219.33 & 219.66 & 328 & 329 & 71.92 & 72.18 \\
\hline Putrescine (4 mM) & 7.17 & 6.89 & 221.33 & 222.00 & 331 & 329 & 73.32 & 73.97 \\
\hline Putrescine (6 mM) & 6.34 & 6.42 & 226.33 & 226.66 & 334 & 335 & 75.75 & 76.02 \\
\hline Spermine (2 mM) & 8.65 & 8.79 & 218.33 & 219.66 & 327 & 332 & 71.40 & 72.04 \\
\hline Spermine (4 mM) & 7.95 & 8.11 & 221.33 & 223.00 & 332 & 332 & 73.40 & 74.02 \\
\hline Spermine (6 mM) & 6.85 & 6.74 & 226.66 & 227.00 & 335 & 336 & 75.94 & 76.43 \\
\hline Jasmine Oil $(0.04 \%)$ & 9.29 & 9.34 & 210.33 & 211.66 & 318 & 320 & 66.94 & 67.65 \\
\hline Jasmine Oil (0.06 \%) & 8.42 & 8.57 & 227.33 & 228.00 & 326 & 327 & 74.11 & 74.57 \\
\hline Jasmine Oil (0.08 \%) & 7.52 & 7.57 & 232.00 & 232.33 & 332 & 333 & 76.94 & 77.36 \\
\hline Thyme Oil (0.04 \%) & 9.16 & 8.95 & 209.66 & 210.00 & 320 & 322 & 67.18 & 67.49 \\
\hline Thyme Oil (0.06 \%) & 8.24 & 8.09 & 225.00 & 226.00 & 326 & 329 & 73.34 & 74.27 \\
\hline Thyme Oil (0.08 \%) & 7.22 & 7.37 & 230.33 & 231.66 & 334 & 335 & 76.92 & 77.52 \\
\hline Garlic Extract ( $1 \%)$ & 8.85 & 8.35 & 210.66 & 211.33 & 322 & 325 & 67.90 & 68.72 \\
\hline Garlic Extract (1.5\%) & 7.24 & 7.12 & 215.33 & 216.66 & 324 & 325 & 69.83 & 70.48 \\
\hline Garlic Extract (2\%) & 6.66 & 6.28 & 219.00 & 219.66 & 326 & 328 & 71.32 & 71.98 \\
\hline Clove Extract (1\%) & 8.57 & 8.65 & 211.00 & 211.33 & 323 & 324 & 68.15 & 68.39 \\
\hline Clove Extract (1.5\%) & 7.20 & 7.02 & 216.33 & 217.00 & 325 & 326 & 70.21 & 70.80 \\
\hline Clove Extract (2\%) & 6.66 & 6.72 & 220.33 & 220.66 & 327 & 328 & 71.95 & 72.36 \\
\hline Algaefol Extract (1\%) & 8.57 & 8.29 & 213.66 & 214.00 & 323 & 324 & 69.07 & 69.19 \\
\hline Algaefol Extract (1.5\%) & 7.20 & 7.28 & 218.33 & 219.33 & 326 & 326 & 71.10 & 71.57 \\
\hline Algaefol Extract (2 \%) & 7.02 & 7.64 & 218.66 & 218.66 & 326 & 329 & 71.29 & 71.86 \\
\hline Jisamar Extract (1 \%) & 8.87 & 8.93 & 213.66 & 214.00 & 325 & 326 & 69.51 & 69.76 \\
\hline Jisamar Extract (1.5\%) & 7.73 & 7.99 & 219.00 & 219.33 & 326 & 326 & 71.31 & 71.49 \\
\hline Jisamar Extract (2 \%) & 6.78 & 6.95 & 220.66 & 221.66 & 329 & 330 & 72.66 & 73.13 \\
\hline LSD at 0.05 & 0.96 & 0.99 & 20.24 & 10.84 & 7.35 & 7.30 & 4.49 & 3.68 \\
\hline
\end{tabular}

\section{Yield:}

Data in Table (5) illustrated fruit yield as number of fruits per tree and kilograms per tree, in 2013 and 2014 seasons. Results showed that all spraying treatments significantly increased yield as number of fruits per tree and kilograms per tree compared with control in both seasons of study. In addition, in two seasons of this study, the statistical analysis showed that the treatments 
of Putrescine at $6 \mathrm{mM}$, Spermine at $6 \mathrm{mM}$, Jasmine Oil at $0.08 \%$ and Thyme Oil at $0.08 \%$ were more effective in increasing yield as number of fruits per tree and kilograms per tree compared with other treatments. The great benefits of these plant extracts, seaweed extracts, polyamines and essential oils on the yield were mainly attributed to their positive action on enhancing growth and nutritional status of the trees in favour of producing higher number of fruits. Also, the increasing yield by seaweed extract (SWE) spraying may be due to association with its hormonal substances present especially cytokinins (better mobilization photosynthesis). These results are in agreement with those obtained by Hegab et al. (2005) spraying Balady oranges with algae extract $(0.125,0.25$ and $0.50 \%)$ and they reported that crop yield increased with increasing rates of algae extract. Moreover, Abd El-Motty et al. (2010), Mohamed et al. (2012), Mohamed and El-Sehrawy (2013) sprayed seaweed extract on different varieties of mango. They reported that seaweed extract treatments improved yield as number of fruits or weight $(\mathrm{kg}) /$ tree.

In addition, Saleem et al. (2008) worked on 'Blood Red' sweet orange to study the effect of aqueous solutions $(0.01 \mathrm{mM})$ of putrescine, spermidine, spermine and the mixture of all three $(0.001 \mathrm{mM}$ each) were sprayed on to whole trees during full bloom. They found that polyamines (PAs) significantly increased yield/tree. Zaghloul et al. (2011) spraying activated jasmine oil on Navel orange trees and they found that the highest rate of jasmine oil $(0.06 \%)$ significantly increased yield as number of fruits and weight $\mathrm{kg} / \mathrm{tree}$ when compared with the other concentrations. So, it seems recommended to use activated jasmine oil on Washington Navel to increase yield.

\section{Physical properties:}

\section{1. Average fruit weight:}

Data of the present investigation in Table (5) showed the effect of preharvest spraying treatments on average fruit weight of Washington Navel orange trees, in 2013 and 2014 seasons. In both seasons of study, results showed that all treatments significantly increased average fruit weight compared with control. In addition, in two seasons of this study, the statistical analysis showed that Putrescine at $6 \mathrm{mM}$, Spermine at $6 \mathrm{mM}$, Jasmine Oil at $(0.06$ and 0.08$) \%$ and Thyme Oil at $(0.06$ and 0.08$) \%$ were more effective in increasing average fruit weight compared with other treatments. In accordance with these results are those previously found by Ali et al. (2010) working on Canino apricots cultivar and they reported that spraying polyamines (Put) and (Spm) commonly increased fruit weight compared to control. In other studies, similar results were obtained by Abd El-Motty et al. (2010), Mohamed et al. (2012), Mohamed and El- Sehrawy (2013) spraying seaweed extract on different varieties of mango. They reported that seaweed extract treatments improved fruit weight (g) comparing with the control. In addition, these results agreed with those obtained by Zaghloul et al. (2011) spraying activated jasmine oil on Navel orange trees and they found that the highest rate of jasmine oil $(0.06 \%)$ significantly increased the average of fruit weight.

\section{Chemical properties:}

\subsection{Total soluble solids:}

Data concerning the effect of various treatments on fruit total soluble solids content of Washington Navel orange, in 2013 and 2014 seasons are 
showed in Table (6). Results showed that in both seasons, all treatments caused a significant increase in total soluble solids percentage compared with the control. Moreover, the statistical analysis showed that, in 2013 and 2014 seasons, Jasmine Oil at $0.08 \%$, Thyme Oil at $0.08 \%$, Clove Extract at $2 \%$, Algaefol Extract at $2 \%$ and Jisamar Extract at (1.5 and 2)\% were more effective on increasing fruit total soluble solids percentages than other treatments.

Table (6): Effect of some natural pre-harvest foliar applications on total soluble solids, acidity, TSS/Acid and vitamin C of Washington Navel Orange fruits in 2013 and 2014 seasons

\begin{tabular}{|c|c|c|c|c|c|c|c|c|}
\hline \multirow{2}{*}{ Treatments } & \multicolumn{2}{|c|}{ TSS (\%) } & \multicolumn{2}{|c|}{$\mathrm{AC}(\%)$} & \multicolumn{2}{|c|}{ TSS/Acid (\%) } & \multicolumn{2}{|c|}{$\begin{array}{c}\text { Vitamin C } \\
\text { (mg/100 mljuice) }\end{array}$} \\
\hline & 2013 & 2014 & 2013 & 2014 & 2013 & 2014 & 2013 & 2014 \\
\hline Control (Water Only) & 10.00 & 10.16 & 1.33 & 1.33 & 10.60 & 10.70 & 52.70 & 52.31 \\
\hline Putrescine (2 mM) & 11.16 & 11.33 & 0.97 & 1.03 & 12.36 & 12.68 & 57.42 & 57.42 \\
\hline Putrescine (4 mM) & 11.33 & 11.56 & 0.93 & 0.92 & 12.73 & 13.14 & 58.60 & 58.84 \\
\hline Putrescine (6 mM) & 11.83 & 12.26 & 0.88 & 0.86 & 13.44 & 14.15 & 60.57 & 60.80 \\
\hline Spermine (2 $\mathrm{mM})$ & 11.50 & 11.60 & 0.97 & 0.97 & 13.07 & 12.93 & 57.03 & 57.26 \\
\hline Spermine (4 mM) & 11.50 & 11.90 & 0.93 & 0.87 & 12.77 & 13.72 & 59.00 & 58.76 \\
\hline Spermine (6 mM) & 11.66 & 12.13 & 0.88 & 0.86 & 13.15 & 14.15 & 60.96 & 61.20 \\
\hline Jasmine Oil (0.04 \%) & 11.00 & 11.63 & 1.10 & 1.04 & 11.14 & 13.06 & 56.24 & 56.24 \\
\hline Jasmine Oil $(0.06 \%)$ & 11.66 & 11.86 & 1.02 & 0.90 & 11.62 & 13.74 & 58.60 & 58.68 \\
\hline Jasmine Oil $(0.08 \%)$ & 12.33 & 12.33 & 1.00 & 0.84 & 12.08 & 14.34 & 61.36 & 61.27 \\
\hline Thyme Oil (0.04 \%) & 11.33 & 11.43 & 1.11 & 1.03 & 11.40 & 12.94 & 55.84 & 55.85 \\
\hline Thyme Oil (0.06 \%) & 12.00 & 12.13 & 1.00 & 0.90 & 11.95 & 14.15 & 58.60 & 58.68 \\
\hline Thyme Oil $(0.08 \%)$ & 12.16 & 12.40 & 0.99 & 0.84 & 11.88 & 14.70 & 60.96 & 61.12 \\
\hline Garlic Extract (1\%) & 11.50 & 11.56 & 0.96 & 0.96 & 12.87 & 13.14 & 56.64 & 56.63 \\
\hline Garlic Extract (1.5\%) & 11.66 & 11.80 & 0.91 & 0.89 & 13.25 & 13.83 & 57.82 & 58.37 \\
\hline Garlic Extract ( $2 \%)$ & 11.83 & 12.00 & 0.86 & 0.84 & 13.75 & 14.28 & 59.00 & 58.91 \\
\hline Clove Extract (1\%) & 11.66 & 11.66 & 0.92 & 0.96 & 13.03 & 13.51 & 57.03 & 57.26 \\
\hline Clove Extract $(1.5 \%)$ & 11.83 & 11.96 & 0.91 & 0.90 & 13.48 & 14.08 & 57.82 & 57.97 \\
\hline Clove Extract (2\%) & 12.00 & 12.13 & 0.86 & 0.83 & 13.89 & 14.50 & 59.00 & 58.99 \\
\hline Algaefol Extract (1\%) & 11.50 & 11.80 & 0.96 & 0.93 & 12.86 & 13.60 & 56.24 & 56.24 \\
\hline Algaefol Extract (1.5\%) & 11.66 & 12.06 & 0.95 & 0.89 & 13.25 & 14.36 & 58.21 & 58.60 \\
\hline Algaefol Extract (2\%) & 12.00 & 12.30 & 0.89 & 0.83 & 14.16 & 14.75 & 59.78 & 60.02 \\
\hline Jisamar Extract (1\%) & 11.66 & 11.76 & 0.96 & 0.96 & 13.10 & 13.89 & 57.03 & 57.19 \\
\hline Jisamar Extract (1.5\%) & 12.00 & 12.16 & 0.92 & 0.89 & 13.63 & 14.48 & 58.60 & 58.76 \\
\hline Jisamar Extract (2\%) & 12.16 & 12.33 & 0.85 & 0.82 & 14.19 & 14.91 & 60.18 & 60.17 \\
\hline LSD at $_{0.05}$ & 0.72 & 0.66 & 0.09 & 0.13 & 1.21 & 1.64 & 3.16 & 2.95 \\
\hline
\end{tabular}

These results are in agreement with those obtained by Hegab et al. (2005) working on Balady oranges and they reported that total soluble solids content increased with increasing rates of algae extract. As well as, Abd El-Motty et al. (2010), Mohamed et al. (2012), Mohamed El- Sehrawy (2013) spraying seaweed extract on different varieties of mango and they found that spraying trees with algae extract increased total soluble solids. Moreover, Saleem et al. (2008), Kassem et al. (2012) spraying putrescine on different varieties of orange and they found that total soluble solids (TSS) significantly improved with polyamines compared with control. Where, these results are on the contrary 
with those obtained by Zaghloul et al. (2011) spraying activated jasmine oil on Navel orange trees and they found that untreated (control) fruits recorded the highest values of S.S.C compared to jasmine oil treated fruits in both seasons. So, it seems recommended to use activated jasmine oil on Washington Navel to improve fruit quality and delayed ripening.

\subsection{Vitamin C (Ascorbic Acid):}

With respect to the effect of various applied treatments on ascorbic acid content in juice of Washington Navel orange fruits, in both experimental seasons, the data demonstrated in Table (6) declared that as an average of all used treatments, the initial of Ascorbic acid significantly increased in both seasons compared with control. Moreover, the statistical analysis showed that putrescine at $6 \mathrm{mM}$, Spermine at $2 \%$, Jasmine Oil at $0.08 \%$, Thyme Oil at $0.08 \%$ and Jisamar Extract at $2 \%$ were more effective on increasing ascorbic acid (mg/100 juice) than that of other treatments. In accordance with these results, are those previously found by Hegab et al. (2005) working on Balady oranges and they reported that vitamin $\mathrm{C}$ content increased with increasing rates of algae extract. Moreover, Zaghloul et al. (2011) spraying activated jasmine at two rates $(0.03$ and 0.06$) \%$ on Navel orange trees and they reported that treated fruits had the highest V.C content than control at harvest time. In addition, Fatemi et al. (2011) working on Citrus Sinensis cv. Valencia and showed that the highest level of vitamin C (54.93 $\mathrm{mg})$ was observed in thyme treatment (1000 ppm). Kassem et al. (2012) spraying putrescine on Washington Navel orange trees and found that all sprayed treatments increased vitamin $\mathrm{C}$ content.

\subsection{Acidity:}

Data concerning the effect of various treatments on fruit acidity content of Washington Navel orange in 2013 and 2014 seasons, are showed in Table (6). In both seasons results revealed that, generally, all treatments significantly decreased fruit juice acidity compared with control. In addition, the statistical analysis showed that putrescine at $6 \mathrm{mM}$, Spermine at $6 \%$, Garlic Extract at 2 $\%$, Clove Extract at 2\%, Algaefol Extract at $2 \%$ and Jisamar Extract at $2 \%$ were more effective on decreasing acidity percentages than other treatments. These results are in harmony with those obtained by Hegab et al. (2005) working on Balady oranges and they reported that fruit total acidity decreased with increasing rates of algae extract. Ali et al. (2010) working on Canino apricots cultivar and they reported that fruit acidity was lower than control at all polyamines treatments. As well as, Mohamed et al. (2012), Mohamed and ElSehrawy (2013) spraying seaweed extract on different varieties of mango. They reported that treating the trees with seaweed extract (SWE) at 0.1 to $0.4 \%$ twice, thrice or four times significantly improved chemical characteristics of the mango fruits in terms of decreasing total acidity percentages in relative to the check treatment. Where, these results are on the contrary with those obtained by Fatemi et al. (2011) working on Citrus Sinensis cv. Valencia and showed that total acidity content had shown significant difference in inoculated and non inoculated fruits affected by treatments. The highest total acid value was observed in non-inoculated fruits of thyme treatment with $100 \mathrm{ppm}$ concentration (1.49 mg). Also, Zaghloul et al. (2011) spraying activated jasmine 
at two rates $(0.03 \%$ and $0.06 \%)$ on Navel orange trees and they reported that acidity values were not affected.

\subsection{TSS/Acid ratio:}

Data of studying the effect of some natural pre-harvest foliar applications on TSS/Acid ratio of Washington Navel orange at harvest are listed in Table (6). In the two seasons of study 2013 and 2014, results showed that all treatments caused a significantly increase in TSS/Acid ratio comparing with control, except for Jasmine Oil at $0.04 \%$ and Thyme Oil at $0.04 \%$ in 2013 season where the differences were not big enough to be significant. Moreover, in the two seasons of study, the statistically analysis showed that Putrescine at $6 \mathrm{mM}$, Spermine at $6 \mathrm{mM}$, Garlic Extract at (1.5 and 2)\%, Clove Extract at (1.5 and 2 )\%, Algaefol Extract at (1.5 and 2)\% and Jisamar Extract at (1.5 and 2$) \%$ were more effective on increasing TSS/Acid ratio than other treatments. This results are in agreement with those obtained by Ali et al. (2010) working on Canino apricots cultivar and they reported that SSC/Acidity ratio was higher in all Putrescine and Spermine treatments compared to control.

\subsection{Reducing sugars:}

Data concerning the effect of various treatments on fruit reducing sugars percentage of Washington Navel orange in 2013 and 2014 seasons are shown in Table (7). In both seasons, results revealed that, generally, all treatments significantly increased fruit reducing sugars percentage compared with control. Moreover, in the two seasons of study, the statistically analysis showed that Putrescine at $6 \mathrm{mM}$, Spermine at $6 \mathrm{mM}$, Jasmine Oil at $0.08 \%$, Thyme Oil at $(0.06$ and 0.08$) \%$, Garlic Extract at (1.5 and 2)\%, Clove Extract at (1.5 and $2) \%$, Algaefol Extract at (1.5 and 2)\%, Jisamar Extract at (1.5 and 2$) \%$ are more effective in increasing fruit reducing sugars percentage compared with other treatments. The increase in reducing sugars may be attributed to accumulation of sugars as a result of the metabolism of polysaccharaides. These results are in harmony with those obtained by Hegab et al. (2005) working on Balady oranges and they reported that reducing sugars content increased with increasing rates of algae extract. Moreover, Saleem et al. (2008) working on 'Blood Red' sweet orange and they found that reducing sugars significantly improved with polyamines compared with control. Also, Kassem et al. (2012) spraying putrescine on Washington Navel orange trees and found that all sprayed treatments increased reducing sugars content. In addition, Mohamed et al. (2012), Mohamed and El-Sehrawy (2013) spraying different varieties of mango. They reported that treating the trees with seaweed extract (SWE) at 0.1 to $0.4 \%$ twice, thrice or four times significantly improved chemical characteristics of the mango fruits in terms of increasing reducing sugars percentage.

\section{6. Non-reducing sugars:}

Data of studying the effect of some natural pre-harvest foliar applications on fruit non-reducing sugars percentage of Washington Navel orange at harvest are listed in Table (7). Results, generally, showed that the non-reducing sugars did not show a constant or regular trend in both seasons. Even that, it showed a significant increase compared with control for all treatments, except for Putrescine at $2 \mathrm{mM}$, Jasmine Oil at $(0.04$ and 0.06$) \%$, Thyme Oil at $(0.04,0.06$ 
and 0.08$) \%$, Garlic Extract at 2\%, Clove Extract at (1.5 and 2)\% and Algaefol Extract at $2 \%$ where the differences were not big enough to be significant in the first year of study.

Table (7): Effect of some natural pre-harvest foliar applications on reducing sugars, non-reducing sugars and total sugars percentage of Washington Navel orange fruits in 2013 and 2014 seasons

\begin{tabular}{|c|c|c|c|c|c|c|}
\hline \multirow{2}{*}{ Treatments } & \multicolumn{2}{|c|}{$\begin{array}{c}\text { Reducing Sugars } \\
(\%)\end{array}$} & \multicolumn{2}{|c|}{$\begin{array}{c}\text { Non-Reducing } \\
\text { Sugars }(\%) \\
\end{array}$} & \multicolumn{2}{|c|}{$\begin{array}{c}\text { Total Sugars } \\
(\%)\end{array}$} \\
\hline & 2013 & 2014 & 2013 & 2014 & 2013 & 2014 \\
\hline Control (Water Only) & 3.62 & 3.58 & 3.40 & 3.54 & 7.02 & 7.13 \\
\hline Putrescine (2 mM) & 3.79 & 3.82 & 3.52 & 3.47 & 7.31 & 7.29 \\
\hline Putrescine (4 mM) & 3.87 & 3.88 & 3.57 & 3.57 & 7.44 & 7.45 \\
\hline Putrescine (6 mM) & 3.91 & 3.94 & 3.66 & 3.65 & 7.58 & 7.60 \\
\hline Spermine (2 mM) & 3.77 & 3.81 & 3.56 & 3.54 & 7.33 & 7.35 \\
\hline Spermine (4 mM) & 3.86 & 3.90 & 3.62 & 3.59 & 7.48 & 7.50 \\
\hline Spermine $(6 \mathrm{mM})$ & 3.91 & 3.96 & 3.69 & 4. 67 & 7.60 & 7.64 \\
\hline Jasmine Oil (0.04 \%) & 3.79 & 3.79 & 3.54 & 3.56 & 7.33 & 7.35 \\
\hline Jasmine Oil (0.06 \%) & 3.90 & 3.88 & 3.47 & 3.53 & 7.37 & 7.42 \\
\hline Jasmine Oil (0.08 \%) & 3.93 & 3.91 & 3.65 & 3.66 & 7.58 & 7.58 \\
\hline Thyme Oil (0.04\%) & 3.83 & 3.80 & 3.53 & 3.57 & 7.35 & 7.38 \\
\hline Thyme Oil (0.06 \%) & 3.93 & 3.91 & 3.53 & 3.56 & 7.46 & 7.48 \\
\hline Thyme Oil (0.08 \%) & 3.99 & 4.01 & 3.55 & 3.57 & 7.54 & 7.58 \\
\hline Garlic Extract (1\%) & 3.84 & 3.82 & 3.58 & 3.61 & 7.42 & 7.44 \\
\hline Garlic Extract (1.5\%) & 3.94 & 3.96 & 3.60 & 3.61 & 7.54 & 7.58 \\
\hline Garlic Extract (2\%) & 4.05 & 4.02 & 3.45 & 3.63 & 7.50 & 7.66 \\
\hline Clove Extract (1\%) & 3.84 & 3.81 & 3.60 & 3.65 & 7.44 & 7.46 \\
\hline Clove Extract $(1.5 \%)$ & 3.96 & 3.94 & 3.52 & 3.65 & 7.48 & 7.60 \\
\hline Clove Extract ( $2 \%$ ) & 4.07 & 4.03 & 3.55 & 3.60 & 7.62 & 7.64 \\
\hline Algaefol Extract (1\%) & 3.84 & 3.84 & 3.62 & 3.61 & 7.46 & 7.46 \\
\hline Algaefol Extract (1.5\%) & 3.94 & 3.96 & 3.60 & 3.63 & 7.54 & 7.60 \\
\hline Algaefol Extract (2\%) & 4.06 & 4.03 & 3.52 & 3.62 & 7.58 & 7.66 \\
\hline Jisamar Extract (1\%) & 3.84 & 3.82 & 3.64 & 3.67 & 7.48 & 7.50 \\
\hline Jisamar Extract (1.5\%) & 3.96 & 3.91 & 3.62 & 3.70 & 7.58 & 7.62 \\
\hline Jisamar Extract (2 \%) & 4.06 & 4.00 & 3.64 & 3.67 & 7.70 & 7.68 \\
\hline LSD $_{0.05}$ & 0.15 & 0.17 & 0.16 & 0.13 & 0.09 & 0.10 \\
\hline
\end{tabular}

In 2014 season, results showed a non-significant increase compared with control for all treatments, except for Jisamar Extract at (1, 1.5 and 2)\% where the differences were big enough to be significant while, it showed a nonsignificant decrease for Putrescine at $2 \mathrm{mM}$ and Jasmine Oil at $0.06 \%$ in the same season. These results are in agreement with those obtained by Marzouk and Kassem (2010) worked on Washington Navel orange trees and they repotted that, preharvest foliar sprays with putrescine increased non-reducing sugars content compared with the control. 


\section{7. Total sugars:}

Results of the present investigation, presented in Table (7) showed the effect of some natural pre-harvest foliar applications on total sugars content of Washington Navel orange fruit at harvest in 2013 and 2014 seasons. Data showed that, in both seasons, all treatments caused a significant increase in total sugars content compared with control. Moreover, in the two seasons of study, the statistically analysis showed that Putrescine at $6 \mathrm{mM}$, Spermine at 6 $\mathrm{mM}$, Jasmine Oil at $0.08 \%$. Thyme Oil at $0.08 \%$, Garlic Extract at $(1.5$ and 2)\%, Clove Extract at (1.5 and 2 )\%, Algaefol Extract at (1.5 and 2)\% and Jisamar Extract at (1.5 and 2)\% were more effective on increasing total sugars than other treatments. These results are in agreement with those obtained by Hegab et al. (2005) working on Balady oranges and they reported that total sugars content increased with increasing rates of algae extract. Moreover, Saleem et al. (2008) working on 'Blood Red' sweet orange and they found that total sugars significantly improved with polyamines compared with control. Also, Kassem et al. (2012) spraying putrescine on Washington Navel orange trees and found that all sprayed treatments increased total sugars content. In addition, Mohamed et al. (2012), Mohamed and El-Sehrawy (2013) spraying seaweed extract on different varieties of mango. They reported that treating the trees with seaweed extract (SWE) at 0.1 to $0.4 \%$ twice, thrice or four times significantly improved chemical characteristics of the mango fruits in terms of increasing total sugars percentage.

\section{CONCLUSION}

Foliar applications with Putrescine, Spermine, Jasmine Oil, Thyme Oil, Garlic Extract, Clove Extract, Algaefol Extract and Jisamar Extract on Washington Navel orange trees four times after full bloom, increased the yield, improved leaf mineral contents and fruit quality. In addition, Results declared that the higher concentrations of treatments were more effective than the low concentration on yield and fruit quality of Washington Navel orange fruits.

\section{REFERENCES}

Abd El-Motty, E. Z. A., M. F. M. Shahin, M. H. El-Shiekh and M. M. M. Abd El-Migeed. 2010. Effect of Algae Extract and Yeast Application on Growth, Nutritional Status, Yield and Fruit Quality of Keitte Mango trees. Agriculture and Biology Journal of North America, 1(3): 421-429.

Ali, E. A. M., S. M. A. Sarrwy and H. S. A. Hassan. 2010. Improving Canino Apricot Trees Productivity by Foliar Spraying with Polyamines. Journal of Applied Sciences Research; 2010. September, 1359-1365. 26 ref.

Apelbaum, A., A. C. Burgoon, J. D. Anderson and M. Lieberman. 1981. Polyamines Inhibit Biosynthesis of Ethylene in Higher Plant Tissue and Fruit Protoplast. Plant Physiol., 68: 239-247.

Asghari, M. A., Y. Mostufi, S. H. Shoheibi and M. Moghomiv. 2009. Effect of Basil Essential on Control Decay Gray Mould and Postharvest Quality of Strawberry cv. Selvia. Journal. Medicinial Plants. A Quarterly Med. Plants., 8(28): 131-139 (In Persian).

Association of Official Agriculture Chemists. (A.O.A.C.). 1980. Official Methods of Analytical Chemists, Washington, D. C., U.S.A. 
Avato, P., E. Tursil, C. Vitali, V. Miccolis and V. Candido. 2000. Allylsulfide Constituents of Garlic Volatile Oil as Antimicrobial Agents. Phytomedicine, 7 (3): 239-243.

Bruneton, J., 2011. Farmacogenosia. Zaragoza, Ed. Acriba., pp: 294-296.

Cai, L. and C. D. Wu. 1996. Compounds from Syzygium Aromaticum Possessing Growth Inhibitory Activity Against Oral Pathogens. J. Nat. Prod., 59 (10): 987-990.

Chaieb, K., T. Zmantar, R. Ksouri, H. Hajlaoui, K. Mahdouani, C. Abdelly and A. Bakhrouf. 2007. Antioxidant properties of Essential Oil of Eugenia Caryophyllata and Its Antifungal Activity Against a Large Number of Clinical Candida Species. Mycosis, 50 (5): 403-406.

Cassan, L., I. Jeannin, T. Lamaze and J. F. Morot Gaudry. 1992.The Effect of the A Nodosum Extract Goemar GA14 on the Growth of Spinach. Bot. Marina, 35: 437 - 439.

Dubois, M., K. A. Cilles, J. K. Hamilton, P. A. Rober and F. smith. 1956. Colorimetric Method for Determination of Sugar and Related Substances. Anal. Chem., 28: 350-356.

Evenhuis, B. 1976. Simplified Methods for Foliar Analysis, VII. International Eport, Royal Tropical Institute, Amesterdam.

Evenhuis, B. and P. W. Dewaard. 1980. Principles and Practices in Plant Analysis. FAO Soil Bull., 38(1): 152-163.

El-Sharkawy, Z. A. 1998. Physiological Studies on Jerusalem Artichoke. Ph. D. Thesis. Fac. Agric. Cairo Univ.

Fatemi, S., M. Jafarpour, S. Eghbalsaied, A. Rezapour and H. Borji. 2011. Effect of Essential Oils of Thymus Vulgaris and Mentha Piperita on the Control of Green Mould and Postharvest Quality of Citrus Sinensis cv. Valencia. African Journal of Biotechnology Vol. 10 (66): 14932-14936.

Giovannoni, J. 2001. Molecular Biology of Fruit Maturation and Ripening, Annual Review of Plant Physiology and Molecular Biology, 52: 725-749.

Hegab, M. Y., A. M. A. Sharawy and S. A. G. El-Saida. 2005. Effect of Algae Extract and Mono Potassium Phosphate on Growth and Fruiting of Balady Orange Trees. Bulletin of Faculty of Agriculture, Cairo University, 56 (1): 107-120.

Karimi, Z. and M. Rahemi. 2009. Comparison Extract Oils of Thymol and Caryophyllus and Imazalill Fungicidies on the Decay Penicillium Italicum Citrus Fruits in Cold Storage. J. Sci. Agri. Techniquies, 12 (45) (In Persian).

Kassem, H. A., H. A. Marzouk and R. S. Al-Obeed. 2012. Effect of Putrescine, $\mathrm{GA}_{3}, 2,4-\mathrm{D}$, and Calcium on Delaying Peel Senescence and Extending Harvest Season of Navel Orange. Journal of Applied Horticulture (Lucknow), 14 (1): 56-62.

Ke, D. and R. J. Romani. 1988. Effect of Spermidine on Ethylene Production and the Senescence of Suspension-Cultured Pear Fruit Cell. Plant Physiol. Biochem.., 26: 109-116.

Kramer, G. F., C. Y. Wang and W. S. Conway. 1991. Inhibition of Softening by Polyamines Application in Golden Delicious and Mcintosh Apple. J. of the Amer. Soc. for Hortic. Sci., 116: 813-817.

Lee, M. M., S. H. Lee and K. Y. Park. 1997. Effect of Spermine on Ethylene Biosynthesis in Carnation (Dianthus Caryophyllus L.) Flowers During Senescene. J. Plant Physiol., 151: 68-73. 
Malik, C. P. and M. B. Singh. 1980. Plant Enzymology and Histoenzymology. A Text Manual. Kalyanipub. New Delhi.

Marzouk, H. A. and H. A. Kassem. 2010. Effect of Putrescine, $G_{3}, 2,4-D$, and Calcium on Extending Harvest Season of Navel Orange. Alexandria Science Exchange Journal, 31 (2): 193-200.

Mohamed, A. Y. and O. A. M. El- Sehrawy. 2013. Effect of Seaweed Extract on Fruiting of Hindy Bisinnara Mango Trees. Journal of American Science. 9(6): 537-544.

Mohamed, A. Y., Al. S. Ali and H. H. Mohamed. 2012. Response of Alphonse Mango Trees to Foliar Application of Alage Extract. Minia J. of Agric. Res. \& Develop., 32(2): 297-312.

Murphy, J. and J. P. Riley. 1962. Amodified Single Solution Method for Determination of Phosphate in Natural Water. Anal. Chem. Acta: 27-31, 36.

Norric, J., T. Branson and P.E. Keathley. 2002. Marin Plant Extracts Impact on Grape Yield and Quality . Acta Hort. J., 91: 93-100.

Pandey, S., S. A. Ranade, P. K. Nagar and N. Kumar. 2000. Role of Polyamines and Ethylene as Modulators of Plar Senescence. Journal of Bioscience, 25: 291-299.

Paulin, A. 1986. Influence of Exogenous Sugars on the Evaluation of Senescence Parameters of Petals. ActaHort., 181: 183-193.

Reitz, S. R. and J. T. Trumble. 1996. Effects of Cytokinin-containing Seaweed Extract on Phaseolus lunatus L.: Influence of Nutrient Availability and Apex Removal. Bot Mar 39: 33-38.

Safiner, R. A. and B. G. Baldi. 1990. Polyamines Levels and Tomato Fruit Development: Possible Interaction with Ethylene. Plant Physiology, 92: 547-550.

Saleem, B. A., A. U. Malik, R. Anwar and M. Farooq. 2008. Exogenous Application of Polyamines Improves Fruit Set, Yield and Quality of Sweet Oranges. Acta Horticulture, 768 (21): 125-133.

Sexton, R. and J. A. Robersts. 1982. Cell Biology of Abscission. Ann. Rev. Plant Physiol., 33: 133-162.

Singh, N., M. Verma, D. Mehta and B. K. Mehta. 2005. Two New Lipid Constituents of Nigella Sativa (seeds). Ind. J. Chem., 44: 742-744.

Snedecor, G. W. and W. G. Cochran. 1980. Statistical Methods. 6. ED. The Lowa St. Univ....press Ames U.S.A.

Srimal, R. C. 1997. Turmeric A Brief Review of Medicinal Properties. Fitoterapia, 68(6): 483-494.

Valero, D. D. Martines-Romero and M. Serrano. 2002. The Role of Polyamines in the Improvement of the Shelf Life of Fruit. Trends in Food Science and Technology, 13: 228-234.

Verkleij, F. N. 1992. Seaweed Extracts in Agriculture and Horticulture, a Review Biological Agriculture and Horticultural, 8: 309 - 324.

Yang, Y. C., S. H. Lee, W. J. Lee, D. H. Choi and Y. J. Ahn. 2003. Ovicidal and Adulticidal Effects of Eugenia Cryophyllata Bud and Leaf Oil Compounds on Pediculus Capitis. J. Agric. Food Chem., 51 (17): 48844888.

Zaghloul, A. E., A. E. Abd El-Naiem and H. E. El-Zayat. 2011. Application of Activated Jasmine Oil on Navel Orange Trees: A- Increasing Production and Fruit Quality. J. Agric. Res. Kafer El-Sheikh Univ., 37(2): 358-369. 
Zargari, A. 1992. Medicinial of Plants. Fifth edition, Tehran Univ. Press: 4: 600 (In Persisan).

Zhang, X. and R. E. Schmidt. 1997.The Impact of Growth Regulators on the A Tocopherol Atatus in Water Stressed Poa pratensis L. IntTurfgrass Res. J., 8:1364-1373.

\section{الملخص العربي}

تحسين ثمار البرتقال أبوسرة برش بعض المواد الطبيعية قبل الحصاد أ- المحتوى المعدني والمحصول وجودة الثمار

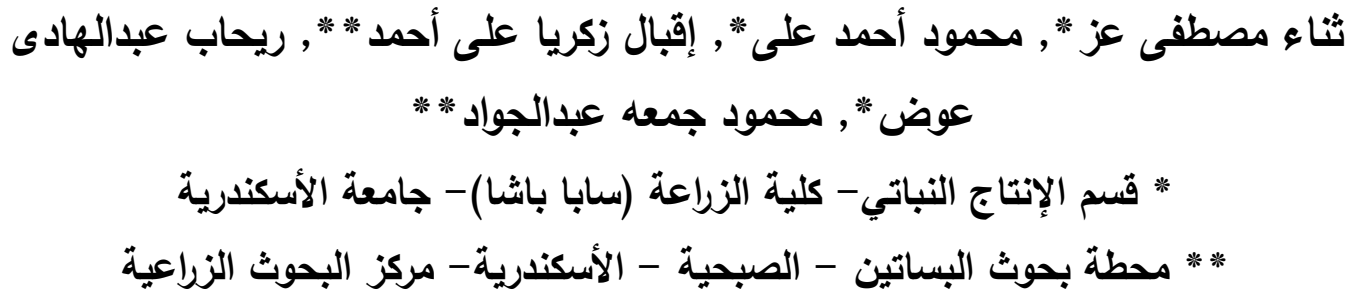

أجريت هذه الدراسة خلال موسمين متتالين (2013 /2014) بهدف دراسة نأثير الرش ببعض المواد الطبيعية قبل الحصاد على المحتوى المعدني والمحصول وجودة ثمار البرتقال أبوسرة وذلك عن طريق الرش قبل الحصاد بكل

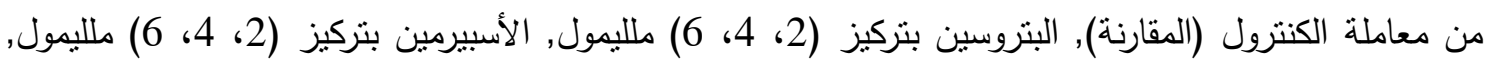

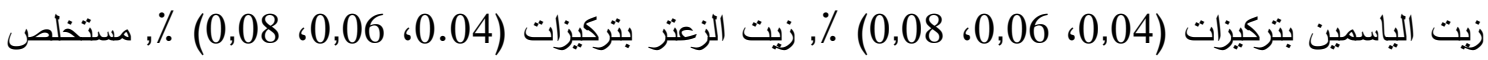

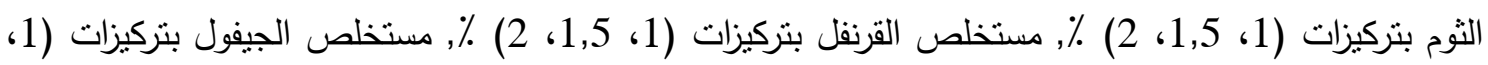

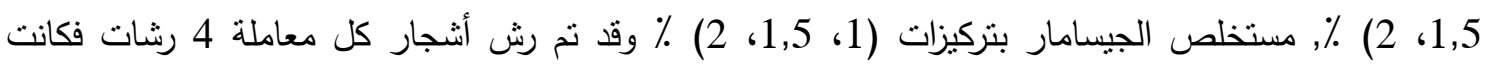

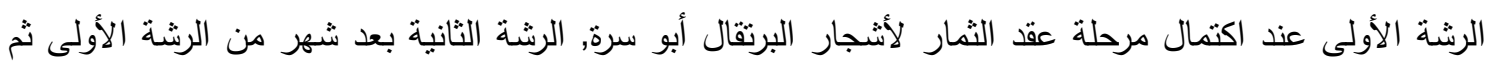
الرشة الثالثة بعد شهر من الرشة الثانية ثم الرشة الرابعة قبل موعد الحصاد بحوالي 45 يوم.

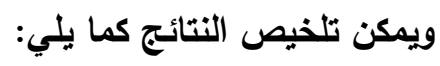

أوضحت النتائج أن جميع المعاملات قد أدت إلى زيادة محتوى الأوراق من النيتروجين, الفسفور , البوتاسيوم, الكالسيوم, الماغنسيوم, الحديد, النحاس, الزنك والمنجنيز عن ئماملة المقارنة, كما كان التركيزان الأعلى (1,5، 2) ٪ من المعاملات مستخلص الثوم, مستخلص القرنفل, مستخلص الجيفول ومستخلص الجيسامار الأفضل في زيادة محتوى الأوراق من العناصر الكبرى والصغرى من باقي المعاملات. أدت جميع المعاملات إلى تقليل النسبة المئوية لتساقط الثمار مقارنة بمعاملة الكنترول, كما أن التركيز الأعلى منى بلى للبتروسين 6 ملليمول, الأسبيرمين 6 ملليمول, مستخلص الثوم 2٪ ومستخلص القرنفل 2٪ كان الأفضل في تقليل تساقط الثمار من باقي المعاملات. أيضا أنضح أن جميع المعاملات قد أدت إلى زيادة المحصول ومتوسط وزن الثمار مقارنة بمعاملة الكنترول,

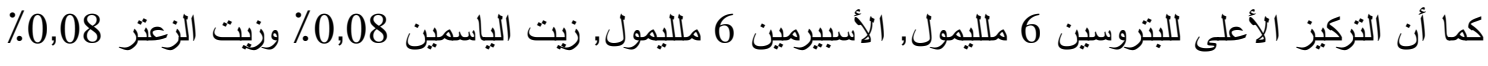
كان أكثر تأثيرا في زيادة المحصول ومتوسط وزن الثمار مقارنة بباقي المعاملات. 
أدت جميع المعاملات إلى زيادة المواد الصلبة الذائبة الكلية, فيتامين (ج), المواد الصلبة الذائبة الكلية إلى الى الحموضة, السكريات المختزلة, السكريات الغير مختزلة, السكريات الكلية وتقليل حموضة الثمار عن معادملة الكنترول, هذا بالإضافة إلى أن التركيزات الأعلى من كل المعاملات المستخدمة كانت لها تأثير أفضل في تحسين جودة ثمار البرثقال أبو سرة عند مقارنتها بالتزكيزات الأقل. 
J. Adv. Agric. Res. (Fac. Agric. Saba Basha) 